\title{
Avaliação de critérios socioambientais na seleção e desenvolvimento de fornecedores de produtos marcas próprias pelo grande varejo brasileiro: um estudo qualitativo múltiplo
}

\section{Environmental and social criteria evaluation in private label products supplier selection and development by Brazilian retail: a multiple qualitative study}

\author{
Omar El Faro' \\ Rogério Cerávolo Calia ${ }^{1}$
}

\begin{abstract}
Resumo: Empresas multinacionais têm se deparado com a necessidade de adotar práticas sustentáveis, ocorrendo o mesmo com grandes redes varejistas. Os produtos marcas próprias, uma vez que carregam a bandeira dos varejistas alinhados à sustentabilidade, acabam tendo que se adequar a estes padrões. Esta pesquisa contribui com a literatura do varejo, pois há poucos estudos envolvendo marcas próprias e seus aspectos socioambientais. Tem como objetivo investigar como e quais são os aspectos socioambientais valorizados pelo varejo em relação aos fornecedores de marcas próprias. Mais do que isso, pretende entender quais certificações e indicadores são utilizados para assegurar se os padrões sustentáveis têm sido respeitados. Para isso, o método de pesquisa adotado foi o qualitativo, tendo como forma de coleta de dados entrevistas semiestruturadas com três dos dez grandes varejistas no Brasil, três fornecedores de marcas próprias e a Abmapro, além de consulta a documentos. A análise dos dados foi feita com a técnica de análise de conteúdo (critério semântico), sendo os dados agrupados em categorias temáticas. Como resultado, obteve-se um panorama sobre quais indicadores socioambientais são exigidos nos contratos de fornecimento e como a verificação do cumprimento desses quesitos ocorre na relação varejo e fornecedores de produtos marcas próprias. Palavras-chave: Marcas próprias; Fornecedores; Varejo; Sustentabilidade; Responsabilidade social.
\end{abstract}

\begin{abstract}
Multinational companies are facing the need to adopt sustainable practices, as well a big retailers. The private label products, that carry the retail flag aligned with sustainability, must fit within these patterns. This research contributes with the retail literature, since there are not many papers about private label and environmental and social sustainability thematic. The goal is to investigate how and which environmental and social criteria are important for retailer regarding private label products supplier's - is innovator. Besides this, this research intends to comprehend what are the certifications and indicators that are used to assure if sustainable patterns have been followed. For this, we adopted the qualitative research method, and the data collection wasthrough semi-structured interviews with three of the big ten retailers of Brazil, three private label product supplier and Abmapro, in addition document research. The data analysis was performed with content analyses technique (semantic criteria), with the data grouped into thematic categories. The main result is a better comprehension and mapping of which environmental and social indicators are required in the supplier's contract and how the compliance verification of these requirements happens in the relationship between retailers and private label product supplier's.
\end{abstract}

Keywords: Private label; Suppliers; Retail; Sustainability; Social responsibility.

\section{Introdução}

Os ideais de Friedman (1970), segundo os quais os gestores devem responder somente aos acionistas, ficaram ultrapassados, mais notadamente quando o conceito de stakeholders veio à tona nos anos 1980. A partir disso, a empresa passa a ter que prestar contas a outros stakeholders além dos acionistas (stockholders). E deve prestar contas não só financeiras, mas também sociais e ambientais.

\footnotetext{
${ }^{1}$ Departamento de Administração, Faculdade de Economia, Administração e Contabilidade de Ribeirão Preto - FEA-RP, Universidade de São Paulo - USP, Avenida dos Bandeirantes, 3900, Monte Alegre, CEP 14040-900, Ribeirão Preto, SP, Brasil, e-mail: omar.elfaro@gmail.com; rogeriocalia@gmail.com
}

Recebido em Ago. 20, 2013 - Aceito em Mar. 26, 2015

Suporte financeiro: Nenhum. 
De acordo com Timlon (2011), empresas que são globais têm se deparado com o risco de não prestar contas nas questões ambientais e sociais. O preço que se paga é alto, pois qualquer deslize ético de um fornecedor, por exemplo, pode resvalar na empresa compradora, podendo causar publicidade adversa, danos à imagem, reputação da empresa compradora e até problemas e custos legais (Reuter et al., 2010). Essa mesma lógica se aplica às grandes cadeias varejistas (algumas delas, inclusive, são globais).

Especificamente no caso das marcas próprias, o estudo de Kremer \& Viot (2012) validou empiricamente a relação de reciprocidade entre a marca própria e a marca do varejista, isto é, as marcas próprias podem influenciar a imagem da marca do varejista e vice-versa. Assim, por transferência de significado, quando as marcas próprias estão associadas ao meio ambiente e satisfazem a necessidade dos consumidores, a imagem do varejista também é melhorada.

Os produtos de marcas próprias, sendo de propriedade do varejista, então, deverão respeitar padrões socioambientais internacionalmente vigentes e que sejam verificáveis. Nisso o varejo assume, ao mesmo tempo, um papel de incentivador e de cobrador desses critérios em relação aos seus fornecedores, elo a montante na cadeia (Parente et al., 2004). Os varejistas, portanto, têm como influenciar toda a cadeia de suprimentos do ponto de vista da sustentabilidade social e ambiental (Wiese et al., 2012; Kotzab et al., 2011; Jones et al., 2011; Lewis et al., 2012).

A propósito, a definição de marcas próprias “[...] diz respeito especificamente àqueles produtos ou marcas que pertencem aos varejistas, atacadistas, associações ou qualquer outro distribuidor de bens de consumo, registrados e comercializados com exclusividade [...]" (ABMAPRO, 2012). Para se ter uma ideia, a participação das marcas próprias no Brasil é de 4,9\%, enquanto em países como Reino Unido alcança 42\%, Suíça 46\%, Espanha 38\%, Holanda $25 \%$, Canadá $18 \%$ e EUA $17 \%$ (ABMAPRO, 2011).

Estudos sobre marcas próprias têm aparecido acompanhados de temas, como: ciclos econômicos e de negócios (recessão, crescimento, renda disponível), comportamento dos consumidores de marca própria, características de varejistas que comercializam marca própria, relacionamento entre indústria fornecedora de marcas próprias e varejistas compradores e características dos produtos de marcas próprias (Gooner \& Nadler, 2012). O estudo de Yokoyama et al. (2012), ao verificar as relações entre varejistas e fornecedores no desenvolvimento de produtos marcas próprias, concentra-se em inovações incrementais desses produtos, sem, no entanto, abordar diretamente inovações social e ambientalmente sustentáveis. Apenas menciona que essas preocupações existem por parte dos varejistas em relação aos fornecedores, mas não aborda como essa preocupação se desdobra em ações de verificação, auditoria, e se tudo isso está assegurado nos contratos ou não.

Questões sociais e ambientais foram comentadas por Burt (2000) e Anselmsson \& Johansson (2007) em produtos de marcas próprias de quarta geração, mas não foram encontrados na literatura nacional e internacional trabalhos tratando especificamente de marcas próprias e sustentabilidade social e ambiental.

Segundo Reuter et al. (2010), é de forte relevância acadêmica e prática investigar como as empresas integram critérios econômicos, ecológicos e sociais em seus processos de fornecimento e decisão sobre fornecedores - em particular aquelas em busca de práticas genuinamente sustentáveis. Num contexto mais geral, os artigos envolvendo sustentabilidade e varejo estão em sua infância (Wiese et al., 2012). Ainda mais, se for considerado o fato de que até a literatura internacional carece de estudos que retratem a questão da sustentabilidade nos varejistas do Brasil (Delai \& Takahashi, 2013).

Os varejistas são pressionados pelo público e pelas agências governamentais para controlar os produtos disponibilizados em suas prateleiras em nível local, mesmo que os produtos tenham sido fabricados em outros países. Com isso, acabam tendo responsabilidade indireta sobre esses produtos. No caso de produtos marcas próprias, a responsabilidade dos varejistas é direta (Lewis et al., 2012).

Assim, se for importante pesquisar as relações entre empresas (varejo) e seus fornecedores no âmbito de práticas sustentáveis, se os estudos envolvendo varejo e sustentabilidade estão em sua infância, e se questões sociais e ambientais estão aparecendo em produtos de marcas próprias da quarta geração, seria oportuno unir esses assuntos (marcas próprias, varejo e sustentabilidade; relação entre empresas fornecedoras ambientalmente e socialmente corretas e o varejo) em torno da seguinte pergunta de pesquisa: Como e quais são os critérios socioambientais que o varejo leva em conta no programa de desenvolvimento e seleção de produtos marcas próprias junto a seus fornecedores?

Eis, portanto, a lacuna de pesquisa a ser preenchida: unir temas de sustentabilidade social e ambiental ao varejo e, especificamente, à quarta geração de produtos marcas próprias, estudando o seu desenvolvimento/seleção pelo varejo junto a seus fornecedores. De modo que o objetivo geral deste artigo é: avaliar como e quais critérios socioambientais o varejo considera no desenvolvimento e seleção de produtos marcas próprias junto a seus fornecedores.

Como desdobramentos do objetivo geral, os objetivos específicos são: investigar se os contratos de fornecimento levam em consideração indicadores e certificações socioambientais; averiguar como os varejistas se asseguram de que os atributos socioambientais estão sendo cumpridos; e analisar 
como o varejo exige os aspectos socioambientais em produtos de marcas próprias importados.

Abrindo um parêntese a respeito da pergunta de pesquisa, Minayo (2012, p. 623) diz que é preciso:

[...] definir o objeto sob a forma de uma pergunta ou de uma sentença problematizadora e teorizá-lo. A indagação inicial norteia o investigador durante todo o percurso de seu trabalho [...] Para tornar o objeto um construto científico é preciso investir no conhecimento nacional e internacional acumulado, dialogando com ele ou em torno dele, caso não haja estudos sobre o mesmo assunto, como ocorre nas investigações exploratórias [...]

Ora, o que se fez até aqui foi justamente levantar o conhecimento nacional e internacional acumulado que dialogasse ou passasse em torno do objeto de estudo, já que não foram encontrados estudos ligados diretamente ao que este artigo se propõe.

Do ponto de vista prático, também é possível dizer que existe no varejo, em âmbito de sua marca institucional, uma tendência de apelo aos temas socioambientais. Então, por uma questão de coerência de imagem institucional e de transferência de significado, as marcas próprias, como estão contidas na esfera do varejo e são de propriedade dele, deverão adotar práticas de respeito ao meio ambiente e ao social, não só no discurso, mas que possam ser verificáveis ou passíveis de auditoria.

Como se trata de um tema pouco estudado, adotou-se a pesquisa de caráter exploratório-qualitativo. Foram aplicadas entrevistas em profundidade semiestruturadas com os gestores de marcas próprias de três dos dez maiores varejistas no Brasil, além de três fornecedores de marcas próprias e também com a presidente da Abmapro (Associação Brasileira de Marcas Próprias e Terceirização).

Este artigo segue abordando temas como: marcas próprias e suas quatro gerações, atributos na seleção dos fornecedores de marcas próprias, método, análise dos resultados e conclusões.

\section{Marcas próprias}

Os varejistas sofrem pressão do público e de agências governamentais para controlar os produtos das suas prateleiras, sobre os quais eles não têm um controle direto e total. Estando inseridos em cadeias de suprimentos globais, os varejistas acabam sendo responsabilizados pelos produtos em nível local, mesmo que não tenham participado efetivamente de sua produção/fabricação e logística. A exceção é quando se trata de produtos marcas próprias, de cujo processo o varejo participa ativamente (Lewis et al., 2012).

As marcas próprias podem ser definidas como sendo patrocinadas ou de propriedade dos varejistas, atacadistas ou distribuidores e são vendidas exclusivamente em suas lojas (Nenycz-Thiel, 2011; Hyman et al., 2010), enquanto as marcas de fabricante são de propriedade das indústrias fabricantes e vendidas para o mercado em geral (Nenycz-Thiel, 2011).

Falando-se dos produtos de marcas próprias, o varejista é responsável não somente pela promoção, distribuição, espaço de prateleira e pela precificação, mas também pela natureza do produto. Isto é, decidem o tamanho, cor, letra e a arte da embalagem dos produtos marca própria, bem como sobre a qualidade e especificações de sabor (Morton \& Zettelmeyer, 2004; Piato et al., 2011). Apesar disso, os custos de desenvolvimento relacionados à busca de insumos, desenvolvimento de amostras e testes sensoriais e físico-químicos são de reponsabilidade do fabricante/fornecedor (Yokoyama et al., 2012).

O termo marca própria é intercambiável, principalmente na língua inglesa. São sinônimos os termos: private label, own-labels, retailer brands, own brands ou store brands (Huang \& Huddleston, 2009). O fato de haver um predomínio da literatura inglesa no tema de marcas próprias não significa que não existam denominações em outros idiomas, como o espanhol. Pérez \& Gallo (2003), por exemplo, referem-se às marcas próprias como las marcas de distribuidor.

\subsection{Evolução do conceito - 4 gerações}

Ao longo dos últimos 50 anos, houve uma evolução das gerações de marcas próprias, notadamente em 4 (quatro) fases ou gerações (Chimhundu et al., 2011; Anselmsson \& Johansson, 2009; Huang \& Huddleston, 2009).

Na primeira geração, as marcas próprias eram genéricas, não tinham nome, usavam tecnologia simples e eram de baixa qualidade e imagem em relação às marcas líderes de fabricante. As marcas próprias da segunda geração eram de média qualidade, porém vistas como de baixa qualidade, comparando-se com as marcas de fabricante e inferior a estas no quesito tecnologia. Já na terceira geração, as marcas de varejo são de qualidade comparável às das marcas líderes de fabricante, com tecnologia muito próxima das marcas de fabricante. Os produtos de marca própria da quarta geração têm qualidade similar ou até superior às marcas líderes, sendo mais inovadores e diferentes das marcas top de fabricantes, com tecnologia superior em alguns casos (Chimhundu et al., 2011).

Complementando a ideia das gerações de marcas próprias, Pérez \& Gallo (2003) afirmam que, no mesmo âmbito temporal, podem conviver duas ou mais gerações que tenham aparecido em momentos diferentes da escala evolutiva de tempo.

No Brasil, segundo o artigo de Yokoyama et al. (2012, p. 554), “[...] o fato de os fabricantes estudados se disporem a desenvolver produtos diferentes e inovadores com valor agregado, revela os primeiros 
indícios de que o mercado brasileiro aproxima-se da quarta geração no estágio de evolução das marcas próprias [...]". No entanto, na Europa, especialmente no Reino Unido, podem ser encontrados exemplos mais consolidados das duas últimas gerações de marcas próprias (terceira e quarta), notadamente nas marcas próprias dos varejistas Marks and Spencer e Tesco (Ailawadi \& Keller, 2004).

Alguns varejistas do Reino Unido têm, inclusive, usado as marcas próprias estrategicamente para fisgar grupos ou nichos de consumidores com novos valores, como aqueles que dão valor a uma alimentação mais saudável, ao bem-estar dos animais ou até mesmo a questões ligadas ao meio ambiente (Burt, 2000; Jonas \& Roosen, 2005; Hyman et al., 2010). Para se ter uma ideia, sete das maiores redes de supermercado varejistas do Reino Unido, como ASDA, Co-OP, Sainsbury, Marks \& Spencer, Safeway, Somerfield e Tesco, recentemente concordaram em incorporar os padrões Social Accountability 8000 e Ethical Trading Initiative em seus códigos de conduta. Ambos os padrões tratam da melhoria das condições de trabalho e da mão de obra dos produtores de países do hemisfério sul que exportam para o mercado europeu (Hatanaka et al., 2005).

Além dessas questões apontadas, os conceitos de responsabilidade social corporativa podem estar ligados às marcas próprias, principalmente às da quarta geração de marcas próprias do Reino Unido, até como estratégia de diferenciação (Anselmsson \& Johansson, 2007). Jonas \& Roosen (2005) afirmam que o estabelecimento de produtos orgânicos como de alta qualidade e segurança pode levar os varejistas a ter um ganho de imagem.

\subsection{A seleção dos fornecedores de marcas próprias}

Piato et al. (2011) mostram que os passos do processo de seleção e avaliação de fornecedores de produtos marcas próprias são: pré-seleção de fornecedores, análise do histórico dos fornecedores, contato preliminar, visita à fábrica dos fornecedores, solicitação de amostras do produto, avaliação das amostras, apresentação das propostas e escolha do fornecedor. Em resumo, os autores abordam os procedimentos clássicos, como avaliação da capacidade produtiva, financeira e de fornecimento, aspectos de qualidade e até aspectos mais atuais, como a responsabilidade socioambiental.

No entanto, não descrevem o que deve ser feito depois que os fornecedores foram selecionados. $\mathrm{O}$ que deve ser feito para verificar se os requisitos avaliados e aprovados pela empresa estão sendo cumpridos? Daí é que surgem as visitas de inspeção e acompanhamento.
É preciso visitar de corpo presente o chão de fábrica e conversar com os funcionários, para assegurar que eles não são cooptados e coagidos para conseguir de fato essas respostas (Zutshi et al., 2009). Não basta apenas realizar o check-list para verificar se tem ou não certificação ou trabalho infantil. São necessárias, então, auditorias constantes nos fornecedores de marcas próprias, planejadas e não planejadas.

A empresa também deve conhecer em profundidade a origem das matérias-primas, insumos e produtos utilizados em sua produção ou nas operações diárias, e ter a garantia de que, nessa origem, os direitos humanos e o meio ambiente são respeitados (Instituto Ethos de Empresas e Responsabilidade Social, 2007).

Parente et al. (2004) lembram que, cadeia a montante, os varejistas podem selecionar produtos feitos por empresas socialmente responsáveis e, cadeia a jusante (em sentido aos consumidores finais), podem auxiliar os consumidores a levarem em conta critérios socioambientais nas decisões de compra, seja pelo fato de disponibilizarem produtos mais sustentáveis, seja pelo fato de disponibilizarem mais informações no próprio ponto de venda.

A Abmapro (Associação Brasileira de Marcas Próprias e Terceirização) estuda uma certificação única que englobará, além dos critérios de qualidade, critérios de responsabilidade social, meio ambiente, saúde e segurança, contando para isso com o apoio de entidades regulamentadoras, como a Anvisa (Agência Nacional de Vigilância Sanitária), o Procon e o Inmetro, de grandes redes varejistas, como o Walmart, o Carrefour e o Pão de Açúcar (Piato et al., 2011). Enquanto isso não acontece, podem ser utilizadas as certificações internacionalmente conhecidas e em vigência no momento. Pois, na opinião de Nidumolu et al. (2009), certificações como FSC (Forest Stewardship Council) e Electronic Product Environmental Assessment Tool são mais rígidas do que a maioria das leis e regulamentações dos países e podem ser aplicadas em transações comerciais internacionais.

As certificações feitas por empresas terceirizadas e por ONGs, independentes de órgãos governamentais e de produtores/fornecedores, têm ganhado cada vez mais a credibilidade de consumidores e dos próprios varejistas. Para o grande varejo, as certificações terceirizadas são mais ágeis do que os órgãos governamentais, conseguindo mais flexibilidade para verificação de atributos por ele exigidos. Para os produtores e fornecedores, o acesso a certificações (e serem auditadas por essas empresas terceirizadas) significa uma oportunidade de conquistar/garantir mercados aos quais os produtores não certificados não terão acesso. Para os consumidores - ativistas ou não -, as certificações e a atuação de ONGs acabam assegurando à sociedade de que a função do varejo não é somente obter lucros econômicos, 
mas também terem bons desempenhos sociais e ambientais, onde quer que essas redes operem no mundo (Hatanaka et al., 2005).

Essas questões envolvendo certificações e auditorias são importantes e devem estar previstas em contratos. Afinal, para Friedman \& Miles (2002), as relações entre empresas, consumidores, fornecedores, ONGs e demais stakeholders são necessárias e, em alguns momentos, podem ser incompatíveis. Essas relações - sendo algumas vezes conflituosas - devem ser pautadas por contratos. Para Williamson (2000), a governança das relações contratuais visa manter a ordem, diminuir conflitos e possibilitar ganhos mútuos. E seguir contratos (principalmente formais) é uma forma de se adequar à Nova Economia Institucional.

\section{Método}

Há poucos estudos voltados especificamente ao problema de pesquisa deste estudo. Com isso, este artigo pode contribuir para avanços na literatura sobre o varejo e a sustentabilidade, mais especificamente sobre os aspectos socioambientais envolvidos no desenvolvimento e seleção de fornecedores de marcas próprias ao grande varejo supermercadista.

Richardson (1999) diz que a escolha do método de pesquisa deriva do problema de pesquisa. E lembra que, quando não se dispõe de informação sobre determinado tema e se deseja conhecer o fenômeno (Richardson, 1999), é indicado um estudo exploratório e qualitativo.

Segundo Doz (2011), a pesquisa qualitativa abre a caixa-preta dos processos organizacionais e propicia uma forte inspiração para novas ideias e agendas de pesquisa. Por tudo isso, optou-se pelo tipo de pesquisa exploratória qualitativa, que trabalha, sobretudo, com informações na forma de texto (Flick, 2004). Essas informações, posteriormente, foram categorizadas e deram guarida para uma análise de conteúdo.

Qu \& Dumay (2011) apontam a existência de três formas ou métodos de entrevista: entrevista estruturada, entrevista semiestruturada e entrevista não estruturada. O método de entrevista estruturada, por sua natureza, permitiria a análise de um número maior de casos/entrevistas, ao passo que o método de entrevista aberta possibilitaria apenas a análise de um caso.

O método escolhido para este artigo foi o de entrevistas semiestruturadas com funcionários em nível gerencial da área de marcas próprias de três dos dez maiores varejistas supermercadistas no Brasil, com gerentes de empresas fornecedoras de marcas próprias e com a presidente da Abmapro. É importante esclarecer que este artigo não foi rotulado como um estudo de caso múltiplo, pois não se pôde visitar pessoalmente as fábricas dos fornecedores e as dependências dos varejistas, perdendo-se uma importante fonte de evidência: a observação do pesquisador no local da pesquisa (Yin, 2010).

A técnica de análise dos resultados utilizada foi a da análise de conteúdo, feita a partir da criação de categorias temáticas. Para Bardin (2011), categorias são classes que reúnem um grupo de elementos sob um título genérico. Esse agrupamento foi efetuado, neste trabalho, em razão das características comuns de elementos, respeitando o critério de categorização semântica.

A codificação auxilia na escolha de unidades de registro, a seleção de regras de contagem e a escolha de categorias. A técnica da contagem foi adotada conforme o Apêndice A. Pelo fato de a amostra de entrevistados não ter sido grande o suficiente, não seria possível generalizar os resultados advindos das frequências e quantificações das ocorrências das palavras. Por isso, a quantificação das escolhas de palavras foi útil para tentar aumentar a precisão da categorização semântica proveniente das falas dos entrevistados. Portanto, as frequências de palavras que compõem um campo semântico orientaram a sua categorização e nomeação.

O campo semântico é composto por palavras-chave (escolhas lexicais e corredores isotrópicos, cujos significados se encaixam debaixo de um paradigma temático, ou eixo de significado central), conforme Citelli (1995) e Carrascoza (1999). Esses paradigmas coincidem com o que foi chamado de variável e, depois, de categoria temática (por critério semântico).

Posteriormente, a interpretação dos resultados se deu a partir da triangulação dos dados coletados de três fontes: perspectivas teóricas, entrevistas semiestruturadas e revisão de documentos disponibilizados pelos varejistas (políticas de fornecimento e relatório de sustentabilidade).

A análise/discussão foi realizada por meio da exposição dos relatos de fornecedores e varejistas, respeitando-se as categorias temáticas (utilizando-se o critério semântico). "Os dados obtidos foram examinados qualitativamente por meio de técnicas de análise comparativa/descritiva entre os comportamentos adotados/relatados pelas empresas." (Yokoyama et al., 2012, p. 549) e afirmações presentes na literatura.

A fim de facilitar a compreensão das análises, foi feito um esquema (Figura 1) indicando qual fornecedor fornece para qual varejista e, num plano maior, a Abmapro envolvendo esses dois elos.

Embora o foco do trabalho seja entender os varejistas, por se tratar de uma abordagem de stakeholders e de relações entre elos de uma cadeia produtiva, decidiu-se entrevistar os fornecedores de marcas próprias também. Na Figura 1, esses atores estão representados por nomes genéricos, pois houve a necessidade de se preservar a identidade das empresas pesquisadas. 


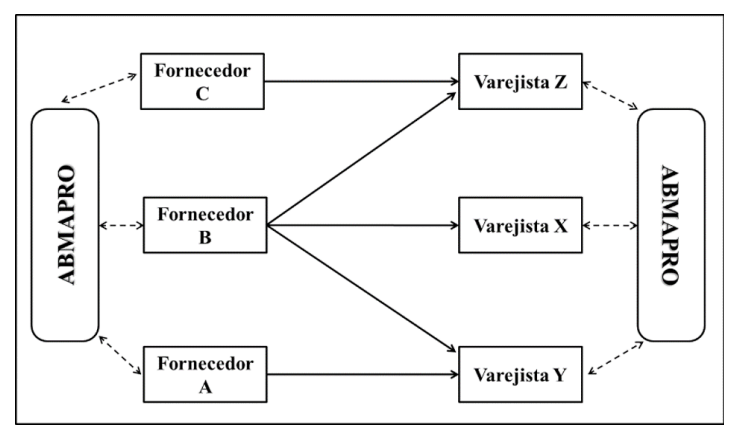

Figura 1. Relações entre fornecedores de marcas próprias, varejo e Abmapro. Fonte: Elaborada pelos autores (2013).

\subsection{Caracterização dos casos}

\subsubsection{Varejista $Y$}

Foi a primeira rede de varejo a disponibilizar pontos de entrega voluntária de materiais recicláveis (papel, plástico, metal, vidro e óleo de cozinha usado) nas suas lojas, chamadas de Estações de Reciclagem (Varejista Y (GPA, 2010)).

O grupo também investe em programas de redução do uso de recursos naturais (água, energia), poluentes e resíduos em algumas de suas lojas e centros de distribuição. Suas fazendas produtoras e fornecedoras de carne são auditadas e assumem o compromisso de desenvolver as comunidades locais, com baixo impacto em matas nativas e com menor emissão de gases de efeito estufa. Também adota a rastreabilidade, que permite identificar a origem do produto e todo seu processo de produção, garantindo maior transparência e qualidade aos clientes.

\subsubsection{Varejista $Z$}

O Varejista Z tem como meta aumentar a oferta de produtos sustentáveis, bem como fazer o alinhamento da cadeia de suprimentos. Assinou também o 'Pacto da Pecuária' e o 'Pacto pela Erradicação do Trabalho Escravo'. E, com relação aos fornecedores, o Varejista $\mathrm{Z}$ realiza uma triagem dos produtores que têm foco em boas práticas trabalhistas, respeitam as leis, preservam o meio ambiente, boas práticas agrícolas, estabelecendo parâmetros desde a produção até a embalagem (Varejista Z (Walmart Brasil, 2010)).

\subsubsection{Varejista $X$}

Além de realizar ações comunitárias, disponibilizar estações de coleta seletiva em algumas lojas e tratar seus resíduos orgânicos, transformando-os em adubo (Varejista X (Carrefour, 2010)), o grupo investe no 'Projeto GTO'.

O selo 'GTO' é aplicado a cerca de 40 produtos perecíveis, divididos nas seguintes categorias: Frutas, Verduras e Legumes, Peixes e Carnes, Queijo e Arroz.
Para os consumidores, as vantagens são: produtos da mais alta qualidade, ecológica e socialmente corretos e com a rastreabilidade (que garante produtos confiáveis, seguros e de qualidade) (Macedo, 2004).

Para isso, o Varejista $\mathrm{X}$ aplica vigilância constante em relação aos fornecedores certificados com o selo, realizando auditoria constante e visitas a campos de cultivo, pastos, abate, armazenamento. Segundo Macedo (2004), os auditores verificam as questões de leis trabalhistas, se não há trabalho escravo infantil, se os uniformes e EPIs (Equipamentos de Proteção Individual) são usados adequadamente, se usam produtos nocivos à saúde, se estão recebendo treinamento adequado quanto à higiene, manuseio de máquinas, manipulação dos alimentos e, ainda, leva em conta o trabalho social realizado com os funcionários e a comunidade.

Especificamente no caso ambiental, o Varejista X tem cinco compromissos principais: "[...] redução do efeito estufa, proteção dos recursos naturais, gerenciamento de resíduos, preservação da qualidade e disponibilidade de água e da biodiversidade [...]" (Macedo, 2004, p. 131).

\subsubsection{Fornecedor B}

Com dez anos de existência, a empresa conta com dois parques industriais, um localizado em Contagem (MG) e outro em Pirapora (MG). Foca seus esforços na produção de alimentos em pó, principalmente amido de milho não transgênico e achocolatado em pó, tendo produção mensal de duas mil toneladas/turno. Fornece produtos marcas próprias para os três maiores varejistas no Brasil. Trabalham nela cerca de 120 funcionários. Seu faturamento anual gira em torno de $\mathrm{R} \$ 200$ milhões.

\subsubsection{Fornecedor A}

Localizada em São Caetano do Sul (SP), a indústria fabrica alimentos como: croutons, biscoitos, batatas fritas, torradas, amendoins e salgadinhos. Foi fundada em 1994 e atualmente fatura em torno de $\mathrm{R} \$ 450 \mathrm{mil}$ por mês, tendo aproximadamente 60 funcionários. Fornece para o pequeno, médio e grande varejista. É fornecedor do maior varejista de origem nacional.

\subsubsection{Fornecedor C}

Criada em 1984, trabalha no ramo de produtos para limpeza automotiva (limpa-vidro, silicone gel, limpa-pneus, lava-autos, cera limpadora).

Instalada no município de Santo André (SP), em uma área de $4.500 \mathrm{~m} 2$, fornece produtos marcas próprias para o maior varejista norte-americano instalado no Brasil. Tem em torno de 60 funcionários. 


\subsubsection{Abmapro}

Com sede em São Paulo-SP, a Abmapro (Associação Brasileira de Marcas Próprias e Terceirização) foi criada em 2006, trazendo para o Brasil uma associação com o propósito de institucionalizar o mercado de marcas próprias e terceirização, tanto no nível B2B (indústria, serviços e varejo), quanto no B2C (consumidor). Presidida por Neide Montesano, tem como missão informar e orientar os empresários da cadeia de marcas próprias, bem como os consumidores brasileiros, sobre as vantagens do fenômeno do "Private Label".

\subsection{Coleta de dados}

No caso deste trabalho, os dados primários foram coletados por meio de entrevistas semiestruturadas e em profundidade com os gerentes de três dos dez maiores varejistas do país, três fornecedores e uma associação do setor, sendo pertinentes ao tema de estudo em questão, conforme o Quadro 1.

Todo o processo - aproximação, realização/gravação e transcrição das entrevistas - ocorreu, conforme o Quadro 1, de outubro de 2012 a maio de 2013.

Os dados secundários foram verificados em consultas a documentos disponibilizados pelos entrevistados e visitas a websites das empresas.

\subsection{Variáveis do estudo e protocolo de pesquisa}

A seguir, no Quadro 2, tem-se o quadro de variáveis, que deu origem às principais perguntas realizadas nas entrevistas. Algumas dessas perguntas podem ser consultadas no Apêndice B - Roteiro de Entrevistas.

Essas variáveis orientaram - e coincidiram - com a criação das categorias temáticas (por critério semântico), presentes nas análises dos resultados. As variáveis surgiram a partir da literatura revisada para este artigo.

\section{Análise dos resultados e discussão}

É oportuno dizer que as análises, embora tenham um teor descritivo, também estabeleceram um 'diálogo' intertextual entre as falas dos entrevistados e a teoria encontrada em autores nacionais e internacionais. Ou seja, procurou-se uma harmonia entre o referencial teórico e o material empírico (trechos das falas dos entrevistados). A seguir, procederam-se as análises das variáveis/categorias temáticas: contratos, verificação e importação.

\subsection{Contratos}

Nesta variável/categoria temática, é oportuno dizer que, segundo Friedman \& Miles (2002), existem graus de relacionamentos entre os stakeholders. Entre eles, estão as relações entre partes consideradas necessárias, porém incompatíveis pelo potencial gerador de conflito, como: empresa e empregado, empresa e governo, empresa e consumidores, empresa e fornecedores e empresa e algumas ONGs. Por esse suposto potencial gerador de conflitos entre as partes e contrapartes envolvidas, seriam necessários contratos pautando essas relações (Williamson, 2000).

Quadro 1. Empresas, datas, cargos, coleta e tempo de duração das entrevistas.

\begin{tabular}{|c|c|c|c|c|c|}
\hline Empresa & $\begin{array}{c}\text { Data da } \\
\text { entrevista }\end{array}$ & Segmento & $\begin{array}{c}\text { Cargo do } \\
\text { entrevistado }\end{array}$ & Forma de coleta & Duração \\
\hline Varejista Z & Março de 2013 & $\begin{array}{c}\text { Varejo } \\
\text { Supermercadista }\end{array}$ & $\begin{array}{c}\text { Gerente de } \\
\text { Garantia de } \\
\text { Qualidade }\end{array}$ & $\begin{array}{c}\text { Ligação por } \\
\text { Skype }\end{array}$ & 27 min \\
\hline Varejista X & $\begin{array}{c}\text { Novembro de } \\
2012\end{array}$ & $\begin{array}{c}\text { Varejo } \\
\text { Supermercadista } \\
\text { Categorias } \\
\text { (marcas próprias) }\end{array}$ & Pessoalmente & 54 min \\
\hline Fornejista Y & Outubro de 2012 & $\begin{array}{c}\text { Varejo } \\
\text { de Marcas } \\
\text { Exclusivas }\end{array}$ & Por e-mail & 5 páginas \\
\hline Fornecedor C & Maio de 2013 & $\begin{array}{c}\text { Limpeza } \\
\text { automotiva }\end{array}$ & $\begin{array}{c}\text { Comercial e de } \\
\text { Marketing }\end{array}$ & $\begin{array}{c}\text { Ligação por } \\
\text { Skype }\end{array}$ & 14 min e $38 \mathrm{~s}$ \\
\hline Fornecedor B & Abril de 2013 & Alimentício & $\begin{array}{c}\text { Sócio-fundador } \\
\text { Skype }\end{array}$ & $\begin{array}{c}\text { Ligação por } \\
\text { Skype }\end{array}$ & 23 min e $57 \mathrm{~s}$ \\
\hline Abmapro & Abril de 2013 & $\begin{array}{c}\text { Associação do } \\
\text { setor }\end{array}$ & $\begin{array}{c}\text { Presidente } \\
\text { Por e-mail }\end{array}$ & 1 página e meia \\
\hline
\end{tabular}

Fonte: Elaborado pelos autores (2013). 
Quadro 2. As perguntas da entrevista.

\begin{tabular}{|c|c|c|c|}
\hline Variável & \begin{tabular}{|c} 
Definição \\
\end{tabular} & Autor & Pergunta \\
\hline Contratos & $\begin{array}{l}\text { A empresa compradora pode } \\
\text { ter cláusulas em contratos com } \\
\text { fornecedores que garantam o respeito } \\
\text { a critérios socioambientais. O não } \\
\text { cumprimento desses contratos pode } \\
\text { penalizar a empresa compradora, } \\
\text { trazendo consequências negativas } \\
\text { para sua imagem e até riscos legais. } \\
\text { Uma das formas de assegurar que } \\
\text { as cláusulas sejam obedecidas é } \\
\text { exigir que seus fornecedores sejam } \\
\text { certificados. }\end{array}$ & $\begin{array}{l}\text { (Timlon, 2011; } \\
\text { Reuter et al., 2010; } \\
\text { Piato et al., 2011) }\end{array}$ & $\begin{array}{l}\text { Quando esta empresa firma } \\
\text { contratos de fornecimento de } \\
\text { produtos marcas próprias, são } \\
\text { levados em conta indicadores } \\
\text { e certificações? Quais? }\end{array}$ \\
\hline Verificação & $\begin{array}{l}\text { Além de cláusulas nos contratos, } \\
\text { exigência de fornecedores } \\
\text { qualificados e certificados, é preciso } \\
\text { ver de perto se tudo isso está sendo } \\
\text { cumprido. Surgem daí as visitas de } \\
\text { inspeção e auditoria, que podem ser } \\
\text { programadas ou não. }\end{array}$ & $\begin{array}{l}\text { (Zutshi et al., 2009) } \\
\text { e (Instituto Ethos } \\
\text { de Empresas e } \\
\text { Responsabilidade Social, } \\
\text { 2007, p. 48). }\end{array}$ & $\begin{array}{l}\text { Como vocês se asseguram } \\
\text { de que as cláusulas de } \\
\text { responsabilidade social } \\
\text { e ambiental estão sendo } \\
\text { efetivamente cumpridas } \\
\text { pelos fornecedores de marca } \\
\text { própria? Como são feitas } \\
\text { as visitas de inspeção aos } \\
\text { fabricantes de marca própria? }\end{array}$ \\
\hline Importação & $\begin{array}{l}\text { Muitos fornecedores de cadeias } \\
\text { varejistas globais operam em outros } \\
\text { países. Mesmo assim, o governo } \\
\text { frequentemente enquadra o varejo } \\
\text { nas jurisdições locais. Na verdade, } \\
\text { o varejo tem um papel menos ativo } \\
\text { no desenvolvimento e formulação } \\
\text { de muitos produtos (importados ou } \\
\text { não) que vende em suas lojas, com } \\
\text { exceção dos produtos marca própria, } \\
\text { cuja responsabilidade é do varejista. }\end{array}$ & $\begin{array}{c}\text { (Lewis et al., 2012; } \\
\text { Hatanaka et al., 2005) }\end{array}$ & $\begin{array}{l}\text { E quando os fornecedores } \\
\text { dos produtos marcas próprias } \\
\text { são de outros países, como } \\
\text { são feitas essas visitas } \\
\text { de inspeção/auditoria } \\
\text { socioambiental? }\end{array}$ \\
\hline
\end{tabular}

Fonte: Elaborado pelos autores (2013).

Nesse sentido, as certificações e as auditorias funcionam como garantia de que os quesitos exigidos pelos varejistas de suas contrapartes (fornecedores de produtos marca própria) sejam de fato cumpridos, podendo ser exigências de qualidade e/ou socioambientais.

No caso do "Varejista Y", o fornecimento de produtos de marcas exclusivas está atrelado e condicionado à realização de auditorias nas quais são exigidas as licenças ambientais inerentes ao negócio de cada fornecedor, bem como sua conformidade com a legislação. Isso tudo é condição essencial para se iniciar o processo de fornecimento. Ao se condicionar o fornecimento a pré-requisitos "atrelados" a contratos, de certa forma isso indica que o varejo está inserido nos princípios da Nova Economia Institucional (Williamson, 2000).

Todo o fornecimento de produtos de marcas exclusivas está atrelado a uma auditoria realizada pelo grupo e nessa auditoria são exigidas todas as licenças ambientais relativas ao negócio de cada fornecedor e o fornecimento somente se inicia com a conformidade com a legislação (Varejista Y).
Para o "Varejista X", as formas de se "proteger" nessa relação com os fornecedores se dá por meio de auditorias e certificações (GFSI e BRC).
Auditoria, produto, preço, é isso que é levado em consideração. [...] Tem um grupo que chama Global Food Safety Iniciative (GFSI), que é europeu, [...] que definiu alguns check-lists, algumas certificações, e a gente aceita, por exemplo, às vezes o fornecedor tem BRC, que é uma certificação internacional. Se ele tem essa certificação, eu não vou precisar auditar. Ele só me apresenta a certificação e já vale que ele tem todo o controle (Varejista X).

$\mathrm{Na}$ entrevista do "Varejista Z", a gerente afirma que nessa questão de responsabilidade social há um outro escopo de avaliação de fornecedores, chamado de compras éticas. E, para enfatizar a importância das compras éticas, faz alusão ao caso envolvendo a empresa Zara, cuja imagem de marca sofreu arranhões depois que foram descobertos fornecedores (fábricas de costura) em cujas dependências trabalhavam funcionários latino-americanos (bolivianos, na maioria) 
em condições análogas ao regime de escravidão. Esses deslizes éticos e suas consequências estão em consonância com o que dizem Timlon (2011) e Reuter et al. (2010). Na verdade, as empresas são corresponsáveis pelo comportamento de seus fornecedores e subfornecedores (Andersen \& Skjoett-Larsen, 2009). Isso se aplica, analogamente, aos fornecedores de produtos marcas próprias ou de marcas de fabricante.

[...] falando dessa questão de responsabilidade social, nós temos um outro escopo de avaliação de fornecedores, que a gente chama de compras éticas, que foca também essa preocupação de questões sociais, até para você ter ideia lá do que aconteceu recentemente com uma empresa do setor têxtil com escândalo de trabalho escravo. Então, há uma preocupação também, uma atitude global da companhia, que tem esse escopo de compras éticas, que vê justamente essa parte social realmente. [...] existem questões ambientais que serão avaliadas ao longo desse processo, porque é contínuo, não é uma e acabou, ela tem uma frequência (Varejista Z).

A título de ilustração, Bardin (2011, p. 222) diz que "[...] a interpretação, ou seja, a compreensão do processo em ato resulta da confrontação dos diferentes indicadores [...]", entre eles as figuras de retórica e alusões. Portanto, o que a entrevistada fez foi se valer de uma alusão para exemplificar sua fala e reforçar a importância do assunto tratado.

\begin{abstract}
Os contratos assinados pelos parceiros com a empresa incluem cláusulas relativas às condições de emprego (limite de horas de trabalho, não adoção de trabalho forçado ou análogo ao escravo e de trabalho infantil, não discriminação de raça, sexo, cor, etnia, orientação sexual, preferência religiosa e deficiência, entre outros), liberdade de associação coletiva e respeito às leis de imigração. Há também orientações sobre as condições de trabalho para garantir segurança e bem-estar e cláusulas relativas ao respeito às leis ambientais (Walmart Brasil, 2012, p. 24).
\end{abstract}

Ainda a respeito do "Varejista Z", foi possível triangular os discursos da entrevista com um documento disponibilizado pela entrevistada: Relatório de Sustentabilidade (Walmart Brasil, 2012). Num trecho desse relatório, intitulado "Zelar pela ética e pelo cumprimento das leis", está escrito que os contratos assinados pelos parceiros com a empresa incluem cláusulas de emprego, como limites de horas de trabalho, não adoção de trabalho forçado e de trabalho infantil. No relatório, está escrito também que há orientações sobre segurança e bem-estar e cláusulas de respeito às leis ambientais.

De acordo com Hatanaka et al. (2005), os consumidores veem os varejistas como responsáveis pela segurança dos produtos que eles vendem, especialmente os produtos de marcas próprias (que carregam a bandeira do varejista). De modo que os varejistas captam as informações e as necessidades dos consumidores e as repassam aos fornecedores, que, por sua vez, vão precisar estar capacitados para desenvolver tais produtos.

Diante disso, Yokoyama et al. (2012) ressaltam que os fornecedores, por exigências dos varejistas, devem possuir determinadas certificações (segurança do produto, responsabilidade social e ambiental) e estarem regularizados de acordo com as obrigações fiscais, tributárias e segurança no trabalho, que são exigidos de qualquer fornecedor, independentemente de serem de marcas próprias ou não.

Hatanaka et al. (2005) são mais precisos e especificam quais são as exigências, revelando algumas empresas terceirizadas e ONGs que são certificadoras nesse processo, tais como: Codex Standard (para segurança alimentar), Good Agricultural Practices, Good Manufacturing Practices e Good Management Practices (padrões ISO 9000), Social Accountability 8000, Ethical Trade Initiative Baseline e padrões Fairtrade (ligados à questão do trabalho e mão de obra), padrões ISO 14000, padrões Rainforest Alliance ECO-OK e Marine Stewardship Council (ligados ao meio ambiente) e padrões e selos que atestem que os alimentos e matérias-primas não são geneticamente modificados.

São exigidas, são exigidas. É condição sine qua non: se você não tem isso, você não faz. [...] Da cadeia produtiva toda, eu tenho que apresentar, por exemplo, os meus produtos marca própria, que eu faço (chocolate em pó de caixa, o amido de milho), todas as embalagens têm que ser certificadas, de empresas certificadas. $\mathrm{O}$ nosso pessoal não pode ter mão de obra escrava durante toda a cadeia de produção, desde o cara lá na fazenda, desde a plantação de milho (no caso do amido), além de não ter transgenia, não pode ter funcionários escravos, não pode ter menor trabalhando, tem que ser um emprego que pague todos os impostos, então começa desde o tratamento especial da matéria-prima (que é auditada também) (Fornecedor B).

Do lado do "Fornecedor B", há a confirmação de que, desde a matéria-prima até o produto final, os elos devem ser certificados, garantindo que em nenhum elo da cadeia em que atua há trabalho escravo ou infantil, e que as empresas pagam seus impostos. Isso confirma a teoria, pois Piato et al. (2011) e Yokoyama et al. (2012) afirmam que a idoneidade ética e moral dos fornecedores (obrigações fiscais, tributárias, segurança no trabalho, certificações relacionadas ao produto, responsabilidade social e ambiental) são cada vez mais exigidas pelos varejistas. Ao repetir as expressões "são exigidas" duas vezes e "é condição sine qua non", a pessoa entrevistada do "Fornecedor B" indica que, de fato, as questões socioambientais estão amarradas via contrato e são 
pré-requisitos para se iniciar o fornecimento ao varejista comprador.

Sim e cada vez mais. Nós fornecemos para o Varejista Y há 14 anos. Quando começou a primeira auditoria, esse ponto não era tão visado. Hoje, cada vez mais (Fornecedor A).

O entrevistado do "Fornecedor A" converge na mesma direção ao dizer que cada vez mais esses aspectos têm sido visados nas auditorias, o que não acontecia há 14 anos, quando começou a fornecer seus produtos ao "Varejista Y".

"Sim, sem dúvida. Isso é amarrado via contrato. Eu posso até perder o fornecimento, caso aconteça algum tipo de desvio de conduta [...]. Então, com certeza, eu vou perder o fornecimento total, além de sofrer as sanções legais. [...] a gente está sendo mais cobrado em relação à parte social [...]. Social, que eu digo, é questão de auditorias da empresa para não ter mão de obra escrava, infantil" (Fornecedor C).

O entrevistado do "Fornecedor C" diz que essas questões de trabalho infantil e escravo estão "amarradas" e exigidas por força de contratos, e vai além, ao dizer que pode até perder o fornecimento de seus produtos marca própria ao varejo, bem como sofrer sanções legais, caso seja detectado algum desvio de conduta. Reuter et al. (2010) confirmam esse ponto de vista, ao afirmarem que qualquer deslize ético de um fornecedor pode causar danos à imagem, reputação do varejista e até problemas e custos legais. Tanto o "Fornecedor A" quanto o "Fornecedor C" são enfáticos em confirmar as exigências constando em contratos, o que se pode perceber ao utilizarem as expressões: "sim e cada vez mais", "sim, sem dúvida".

\subsection{Verificação}

A variável anterior tratou a questão dos contratos, para que pudesse dar início ao fornecimento dos produtos marcas próprias. No entanto, ainda falta analisar, depois de firmado o contrato de fornecimento, quais são os mecanismos que garantem e atestam o cumprimento dos quesitos exigidos pelos varejistas.

O entrevistado do "Varejista Y" afirmou que, depois de iniciado o fornecimento, o fornecedor é auditado novamente. Aqueles que têm pontuações menores nas auditorias de qualidade recebem visitas ou acompanhamento com mais frequência, geralmente de 6 em 6 meses.

Após a auditoria de homologação e o consequente início de fornecimento, o fornecedor é auditado novamente em um período de 4 a 6 meses, dependendo da sua pontuação no índice de qualidade. Fornecedores com um score mais baixo têm uma regularidade maior nas auditorias (Varejista Y).
De acordo com a entrevistada do "Varejista X", há empresas terceirizadas que rotineiramente vão ao ponto de venda e coletam os produtos como consumidores ocultos para análise. A auditoria ocorre uma vez ao ano.

[...] Empresas terceirizadas, como rotina, vão ao ponto de venda e coletam o produto como se fossem o consumidor final mesmo. Então, se tiver de acordo com a legislação, com a informação técnica, está ok, senão chama o cara, apresenta e pede uma contraprova. Auditoria é sempre uma vez por ano, análise de produto no mínimo uma vez por ano (Varejista X).

O "Varejista X" disponibilizou material sobre as políticas da empresa em relação aos fornecedores, abordando questões como respeito aos Direitos Humanos, eliminação do trabalho escravo e infantil, meio ambiente e medidas anticorrupção. Para que essas políticas sejam possíveis, firmas de auditoria terceirizadas realizam visitas não anunciadas aos fornecedores e subcontratados. Esse trabalho de fiscalização também pode contar com o auxílio de ONGs parceiras. Hatanaka et al. (2005) confirmam o exposto no documento do "Varejista X", ao dizerem que a cadeia do varejo tem desenvolvido certificações para práticas sociais e ambientais sustentáveis em parcerias com ONGs, até como maneira de se precaverem do poder de retaliação e publicidade adversa que problemas ambientais e/ou de condição de trabalho possam representar. Essas ONGs e suas certificações são formas de distinguir, por meio de selos identificáveis pelos consumidores, produtos agrícolas 'alternativos' dos produtos agrícolas produzidos da maneira convencional. São formas de se promoverem sistemas alternativos de produção e consumo que sejam social e ambientalmente mais sustentáveis e justos.

Visitas não anunciadas por firmas de auditoria terceirizadas são feitas aos fornecedores e subcontratados. Essa fiscalização pode contar com o auxílio de ONGs parceiras (Social and Ethical charter for our suppliers - Varejista X - Direitos Humanos, Eliminação do trabalho escravo e infantil, Meio ambiente, Anticorrupção).

A entrevistada do "Varejista Z" diz que as auditorias dão o respaldo de que precisam, garantindo que os acordos firmados estão sendo mantidos.

Ao longo da cadeia, existem auditorias que nos dão ferramentas para garantir que muitas das coisas estão sendo mantidas (Varejista Z). 
O Relatório de Sustentabilidade (Walmart Brasil, 2012) disponibilizado pela entrevistada do "Varejista Z" diz a mesma coisa, e acrescenta que a realização de inspeções e auditorias para atestar o cumprimento das condições preestabelecidas estão previstas nos próprios contratos.

Os contratos preveem a possibilidade de realizar inspeções e auditorias para atestar que as condições são realmente efetivas (Walmart Brasil, 2012, p. 24).

Até aqui, percebe-se que o mecanismo principal para atestar o cumprimento das condições firmadas em contrato é a realização de auditorias por empresas terceirizadas. $\mathrm{O}$ fato de serem empresas terceirizadas assegura maior confiabilidade para os consumidores e varejistas (Hatanaka et al., 2005).

Eles utilizam essas certificadoras mundiais, que são, inclusive, para este fim, e vêm nos fazer a auditoria para comprovar tudo aquilo que eles estão nos exigindo [...] (Fornecedor B).

Com a resposta do "Fornecedor B", é possível acrescentar a esse panorama a ideia de que as empresas terceirizadas são certificadoras com atuação em nível mundial.

Pela resposta do "Fornecedor A", pode-se descobrir que as empresas de auditoria contratadas são a BVS (Bureau Veritas) e a SGS. O entrevistado afirma que dois auditores passam de 8 a 9 horas dentro das fábricas (fornecedores) e, desse tempo, ficam $45 \%$ no chão de fábrica, e o resto verificam rastreabilidade e documentação. São atribuídas notas para os quesitos analisados e, posteriormente, os relatórios são enviados à Diretoria do "Varejista Y".

O que o Varejista Y faz é pedir que uma empresa auditora, no caso a BVS ou a SGS, venha até a nossa fábrica e faça auditorias do processo de fabricação dos itens que fornecemos. [...] Eles se atêm às notas e aos valores que a auditoria passa. Quando fecha a auditoria, a auditoria manda uma cópia para a Diretoria do Varejista Y, dizendo: esse fornecedor tem, de 0 a 100 pontos, 30 , ou 40 , ou 90 , ou 100 , então eles vão ter ideia de qual nota nós tiramos para isso [...]. A gente está fazendo uma nova auditoria com empresas especializadas em orgânicos, que chama Ecocert, uma empresa lá de Florianópolis, que audita se a empresa tem ou não condições de fornecer produtos orgânicos (Fornecedor A).

O "Fornecedor A" também revela estar se preparando para ser auditado pela empresa Ecocert, para ver se tem condições ou não de fornecer produtos orgânicos. Aqui se pressupõe uma possível adequação do "Fornecedor A" a uma possível exigência do "Varejista Y", que seria o fornecimento de produtos orgânicos. Isso tudo porque os produtos orgânicos, tendo alta qualidade e segurança para o consumidor final, podem trazer ganhos de imagem ao varejista, confirmando o que foi dito por Jonas \& Roosen (2005).

Já no caso do "Fornecedor C", o órgão que faz as inspeções é a Anvisa, uma agência governamental que analisa as boas práticas de fabricação. Segundo o entrevistado, essas exigências acabam cumprindo bem o que é cobrado, no caso do fornecimento de produtos marcas próprias. Essa afirmação (que valoriza o papel da agência governamental), no entanto, contraria o que Hatanaka et al. (2005) dizem a respeito de uma perda de importância das regulamentações de agências governamentais. Embora tenham tratado do sistema agrícola de produção de alimentos - o que diverge do segmento de limpeza automotiva do "Fornecedor C" -, os autores relatam que, com a globalização da cadeia agrícola alimentícia (envolvendo produtores/fornecedores, varejistas, consumidores e ONGs), as certificações e selos de empresas terceirizadas têm ganhado maior espaço e confiabilidade em relação a padrões de regulamentação governamental. Ao falarem de uma certificação ligada ao setor de madeiras e papel, Nidumolu et al. (2009) também confirmam que certificações de empresas terceirizadas, como a FSC, têm mais confiabilidade e credibilidade do que padrões adotados em muitos países, o que, de certa maneira, acaba contrariando um pouco a fala do entrevistado do "Fornecedor C".

A gente já tem as chamadas boas práticas de fabricação, que são feitas pela ANVISA, que é o nosso segmento, que é limpeza automotiva. O órgão que faz a inspeção sobre os nossos produtos é a ANVISA. Então, ela já solicita uma série de documentações e certificações que são necessárias e que cumprem bem o papel para a parte de marcas próprias. [...] Houve mudanças de frascos. Utilização de frascos só na embalagem PET. Reutilização das águas de chuva. A eliminação total de todos os tipos de solvente que são nocivos. Trocamos os produtos de linha que usavam os chamados solventes pesados. Utilização de solventes ecológicos (Fornecedor C).

O que se pode inferir nesta variável é que, dependendo do tipo de produto, há uma agência ou empresa de auditoria/certificação especializada, não havendo, portanto, um padrão que possa ser replicado a todos os tipos de produto. Talvez como uma forma de responder a esse "dilema", Piato et al. (2011) tenham dito que a Abmapro estuda uma certificação única, englobando critérios de qualidade, responsabilidade social, meio ambiente, saúde e segurança, contando com o apoio de entidades regulamentadoras (como a ANVISA, o Procon e o Inmetro), além da ajuda de três das dez grandes redes varejistas atuantes no Brasil. 


\subsection{Importação}

$\mathrm{Na} 4^{\text {a }}$ (quarta) geração de produtos marcas próprias, os fornecedores passaram a ser internacionais (Silva et al., 2011).

Concomitantemente a isso, há uma tendência de as empresas multinacionais (entre elas os grandes varejistas) terem fornecedores ou fábricas instaladas nos países em desenvolvimento, nos quais as questões ambientais e condições de trabalho nem sempre são aquelas que as leis dos países desenvolvidos (onde ficam as matrizes das grandes empresas) apregoam. Assim, com o aumento das tecnologias e meios de comunicação, bem como as pressões de consumidores conscientes, ONGs, governo, há uma pressão para que esses fornecedores terceirizados se adequem às leis ambientais e trabalhistas vigentes nos países desenvolvidos. As empresas multinacionais são responsáveis, portanto, pelo que acontece com seus parceiros contratados e subcontratados (Andersen \& Skjoett-Larsen, 2009).

Nesses dois contextos, torna-se importante considerar a variável "importação" no caso dos produtos marcas próprias. Inclusive, Yokoyama et al. (2012, p. 555) indicaram a importância de estudar, em futuras pesquisas, "[...] o fato dos fornecedores de países em desenvolvimento apresentarem características peculiares em relação aos países desenvolvidos", em se tratando de processo de desenvolvimento de produtos de marcas próprias. Como dizem Hatanaka et al. (2005), em muitos países em desenvolvimento, os padrões governamentais de exigência de segurança e saúde de produtos são insuficientes para que essas mercadorias ingressem nos mercados mais lucrativos dos países desenvolvidos.

O "Varejista Y" faz a inspeção na origem dos produtos importados para assegurar conformidade com a regulamentação nacional. E, além disso, conta com um departamento de Global Sourcing, que seleciona e audita os fornecedores seguindo normas internacionais, como a BRC (British Retail Consortium).

O grupo adota o critério de inspeção na origem para os produtos importados, garantindo assim a adequação dos produtos com a regulamentação nacional. Há também um departamento de Global Sourcing, que seleciona e audita os fornecedores segundo os critérios de qualidade de normas internacionais, como a BRC (British Retail Consortium), por exemplo (Varejista Y).

De acordo com a entrevistada do "Varejista X", como a BVS e a SGS (que também atuam em nível nacional), são empresas mundiais, então, quando o assunto é importação, elas vão aos fornecedores internacionais e os auditam segundo a legislação de onde os produtos foram produzidos. Depois que os produtos entram no Brasil, via importação, também devem estar adequados às legislações e aos controles sanitários brasileiros.

Hoje, batata tipo Pringles tem fornecedor na China que faz. A BVS, a SGS, são empresas mundiais, então elas vão e auditam. No Chile, na Argentina, por exemplo, frutas secas, nessa época agora, todos os fornecedores na Argentina e no Chile foram auditados. Obedece à legislação do país de origem, mas quando o produto entra no Brasil, tem que obedecer à legislação daqui. Quando o produto entra via importação, tem todos os trâmites legais, de análise de produto, sanitário, tudo (Varejista X).

O "Varejista Z” conta com o Programa de Ética na Cadeia de Suprimentos (Ethical Sourcing), que é aplicado aos fornecedores em nível mundial.

A empresa mantém ainda um Programa de Ética
na Cadeia de Suprimentos (Ethical Sourcing),
aplicado a fornecedores em âmbito mundial. Ele se
refere especialmente aos contratos para importação
direta que não passam pelo Global Merchandise
Centers (GMC) ou pelo Direct Sourcing Group
(DSG) - estruturas da empresa em nível global
(Walmart Brasil, 2012, p. 24).

A entrevistada compara os problemas ambientais relacionados à extração do óleo de palma na Amazônia com possíveis problemas ambientais relacionados ao desmatamento de florestas na Indonésia ou na Malásia.

[...] a gente fala não só no desmatamento da Amazônia, mas a gente pode falar do desmatamento lá na Indonésia, ou lá na Malásia, quando a gente fala em óleo de palma, que é um ingrediente hoje usado já em larga escala em indústria alimentícia e não alimentícia [...] (Varejista Z).

Quando o produto for feito de madeira (incluindo papel e celulose), seja ele importado ou nacional, o varejista e o consumidor conscientes podem se amparar no selo FSC (Forest Stewardship Council), que garante que a madeira não provém de desmatamento ilegal e foi manejada de maneira sustentável.

Segundo Nidumolu et al. (2009), o FSC é um padrão mais exigente do que as leis de muitos países, particularmente quando aplicado ao comércio internacional. Vale dizer que as embalagens cartonadas do "Varejista Z" têm certificação FSC, assim como seu "Fornecedor B" de amido de milho se utiliza de embalagem com selo FSC. Ao fornecer produtos contendo o selo FSC, o "Varejista Z" cumpre seu papel a jusante, que é o de informar e disponibilizar produtos verdes em suas prateleiras, e também a montante, ao selecionar fornecedores certificados com selo ambientalmente correto. De certa forma, isso confirma a importância estratégica do varejo na cadeia produtiva em relação à sustentabilidade social e ambiental, de acordo com Parente et al. (2004). 


\section{Conclusões}

Nos itens a seguir, discutiram-se em que medida a pergunta de pesquisa e os objetivos específicos do trabalho foram respondidos, as contribuições teóricas e práticas e também as limitações do trabalho e sugestões para futuras linhas de pesquisa.

\subsection{Resposta ao problema de pesquisa e aos objetivos geral e específicos}

A pergunta de pesquisa pôde ser respondida mais precisamente pela análise dos resultados das variáveis/categorias temáticas "contratos" e "verificação". A variável/categoria "importação" teve um papel secundário - porém não menos importante - para o desenrolar deste artigo.

- Investigar se os contratos de fornecimento levam em consideração indicadores e certificações socioambientais. Houve indicativos de que, desde a matéria-prima até o produto final, há certificação de que não são empregadas mão de obra escrava e infantil. Foram mencionadas as certificações GFSI, BRC e FSC e o escopo de compras éticas no "Varejista Z", atento às questões de responsabilidade social. Das três certificações que surgiram das respostas dos entrevistados, apenas a FSC estava prevista na revisão de literatura (citado por Nidumolu et al., 2009).

- Averiguar como os varejistas se asseguram de que os atributos socioambientais estão sendo cumpridos. Os dados analisados possibilitam dizer que, para garantir que os acordos firmados estão sendo mantidos e cumpridos, são realizadas inspeções e auditorias periódicas ou sem aviso prévio. Esse trabalho é feito por empresas terceirizadas (SGS e Bureau Veritas), com atuação em nível mundial e eventualmente conta com o suporte de ONGs. Dependendo do tipo de produto, a Anvisa também faz o trabalho de verificação das exigências. Como existe essa variação entre certificações/auditorias governamentais e de empresas terceirizadas, Piato et al. (2011) dizem que a Abmapro estuda uma certificação única, englobando critérios de qualidade, responsabilidade social, meio ambiente, saúde e segurança. $\mathrm{O}$ relato do "Fornecedor C" a respeito da Anvisa contraria a suposta perda de importância das agências reguladoras governamentais apontada por Hatanaka et al. (2005).

- Analisar como o varejo exige os aspectos socioambientais em produtos de marcas próprias importados. Os dados indicam que, quando se trata de produtos marcas próprias importados, os fornecedores são auditados pela BVS e SGS na origem (seguindo normas internacionais) $\mathrm{e}$ também são auditados para entrar no Brasil, seguindo normas nacionais. Nos varejistas Y e Z, há departamentos de Global Sourcing e Ethical Sourcing que selecionam e auditam seus fornecedores internacionais, seguindo certificações como a BRC e FSC. A importância do FSC já havia sido apontada no estudo de Nidumolu et al. (2009).

\subsection{Contribuições teóricas e práticas}

Para Delai \& Takahashi (2013), a literatura internacional carece de estudos retratando o varejo no Brasil e a questão da sustentabilidade. Nesse sentido, este trabalho pôde contribuir para a literatura ao estudar os aspectos socioambientais de três dos dez maiores varejistas brasileiros nos produtos marcas próprias. Pelo Quadro 3, é possível comparar as contribuições teóricas deste artigo com as contribuições do importante estudo realizado por Yokoyama et al. (2012).

Este artigo confirma o indício de haver produtos na quarta geração das marcas próprias no mercado brasileiro, como disseram Yokoyama et al. (2012). Ao mesmo tempo, avança ao sugerir que, no Brasil, os produtos de terceira e quarta gerações de marcas próprias têm começado a vir com atributos socioambientais. Essas características, segundo Burt (2000), Jonas \& Roosen (2005), Anselmsson \& Johansson (2009) e Hyman et al. (2010), estavam mais ligadas a produtos das terceira e quarta gerações de produtos marca própria de grandes varejistas do Reino Unido.

O estudo de Yokoyama et al. (2012, p. 555) sugere a necessidade de estudos comparativos entre fornecedores de países em desenvolvimento e desenvolvidos. "Além disso, o fato de os fornecedores de países em desenvolvimento apresentarem características peculiares em relação aos países desenvolvidos, pode sugerir a realização de um estudo comparativo das práticas adotadas." Embora não tenha sido possível entrevistar fornecedores estrangeiros (nem de países desenvolvidos, nem de países em desenvolvimento - exceto brasileiros), foi possível, com este trabalho, avançar/complementar essa discussão perguntando-se aos varejistas a respeito dos produtos importados. Percebeu-se uma grande presença de produtos advindos de países em desenvolvimento. Como as leis trabalhistas e ambientais nesses países são menos rígidas do que a de países desenvolvidos, percebeu-se a importância da verificação por meio de auditorias e a necessidade de se aperfeiçoar isso via contratos. 
Quadro 3. Comparativo de contribuições teóricas deste artigo em relação ao artigo de Yokoyama et al. (2012).

\begin{tabular}{|c|c|c|}
\hline & Contribuições deste artigo & $\begin{array}{l}\text { Contribuições do artigo de } \\
\text { Yokoyama et al. (2012) }\end{array}$ \\
\hline Objetivos & $\begin{array}{l}\text { Verificar aspectos socioambientais no } \\
\text { desenvolvimento e seleção de fornecedores de } \\
\text { produtos marcas próprias para o varejo. }\end{array}$ & $\begin{array}{l}\text { Propôs descrever a dinâmica de } \\
\text { desenvolvimento de produtos de } \\
\text { marcas próprias, comparando as } \\
\text { práticas adotadas pelos agentes da } \\
\text { cadeia produtiva e verificando como } \\
\text { ocorre o processo de inovação desses } \\
\text { produtos. }\end{array}$ \\
\hline $\begin{array}{l}\text { Opiniões de } \\
\text { varejistas e } \\
\text { fornecedores } \\
\text { a respeito de } \\
\text { sustentabilidade }\end{array}$ & $\begin{array}{l}\text { Oferece os pontos de vista de varejistas } \\
\text { e fornecedores a respeito de exigências } \\
\text { socioambientais. Os fornecedores confirmam as } \\
\text { exigências previstas em contratos e que elas são } \\
\text { auditadas. }\end{array}$ & $\begin{array}{l}\text { Diz que o varejista entrevistado exige } \\
\text { de seus fornecedores cumprimento a } \\
\text { questões socioambientais, pagamento } \\
\text { de tributos, segurança do produto, } \\
\text { segurança no trabalho. No entanto, } \\
\text { essa exigência não é confirmada pelos } \\
\text { trechos de entrevista dos fornecedores } \\
\text { estudados. }\end{array}$ \\
\hline Auditorias & $\begin{array}{l}\text { Durante e depois de o contrato de fornecimento ter } \\
\text { sido fechado. }\end{array}$ & $\begin{array}{l}\text { Durante a fase de desenvolvimento de } \\
\text { produto. }\end{array}$ \\
\hline $\begin{array}{l}\text { Certificações e } \\
\text { custos }\end{array}$ & $\begin{array}{l}\text { Possibilitou identificar algumas certificações } \\
\text { respeitadas no setor (algumas delas terceirizadas). } \\
\text { Os fornecedores devem arcar com os custos de } \\
\text { contratar empresas de auditoria terceirizadas e de } \\
\text { eventuais certificações, como pré-requisito para } \\
\text { tentar competir com outras indústrias fornecedoras } \\
\text { por um contrato de fornecimento de produtos de } \\
\text { marca própria com um grande varejista. }\end{array}$ & $\begin{array}{l}\text { Menciona que alguns custos de } \\
\text { desenvolvimento de produto são } \\
\text { bancados pelos fornecedores, mas não } \\
\text { cita certificações. }\end{array}$ \\
\hline $\begin{array}{l}\text { Segmentos dos } \\
\text { fornecedores } \\
\text { estudados }\end{array}$ & $\begin{array}{l}\text { Além dos segmentos de fornecedores alimentícios, } \\
\text { foi estudado um fornecedor de produtos de limpeza } \\
\text { automotiva. }\end{array}$ & $\begin{array}{l}\text { Focou em fornecedores } \\
\text { exclusivamente do segmento } \\
\text { alimentício. }\end{array}$ \\
\hline Inovações & $\begin{array}{l}\text { Foca produtos de terceira e quarta gerações, com } \\
\text { preocupações socioambientais. }\end{array}$ & $\begin{array}{l}\text { Foca produtos de terceira e quarta } \\
\text { gerações, com inovações incrementais, } \\
\text { visando segmentos de mercado } \\
\text { específico, como macarrão com } \\
\text { linhaça (alimentos saudáveis). }\end{array}$ \\
\hline $\begin{array}{c}\text { Seleção de } \\
\text { fornecedores }\end{array}$ & $\begin{array}{l}\text { Aborda a exigência de adequação dos produtos e } \\
\text { da produção a padrões de sustentabilidade social e } \\
\text { ambiental como pré-requisitos para ser selecionado } \\
\text { e para manter o contrato de fornecimento. }\end{array}$ & $\begin{array}{l}\text { "O processo de desenvolvimento } \\
\text { de produto relatado pelos agentes } \\
\text { se resume no levantamento da } \\
\text { necessidade, escolha do alvo desejado, } \\
\text { análise de viabilidade econômica } \\
\text { e produtiva, desenvolvimento de } \\
\text { amostras, testes bioquímicos e } \\
\text { sensoriais, ajustes de especificação } \\
\text { (se necessário), desenvolvimento da } \\
\text { embalagem e seleção do fornecedor" } \\
\text { (Yokoyama et al., 2012 p. 554). }\end{array}$ \\
\hline
\end{tabular}

Fonte: Elaborado pelos autores (2014).

Evidenciaram-se as principais certificações envolvidas e empresas de auditorias (empresas terceirizadas).

Com relação às contribuições práticas, ao trazer à tona a realidade de três dos dez maiores varejistas no Brasil no que diz respeito aos aspectos socioambientais dos produtos marcas próprias, este artigo pode servir como um guia de orientação aos médios e até aos pequenos varejistas que queiram se adequar a essas novas tendências. Isso porque os produtos de marcas próprias carregam a bandeira do varejista (independentemente de ser grande, médio ou pequeno) e, na medida em que a marca principal se vê pressionada a atender padrões de sustentabilidade social e ambiental, por transferência de significado essas exigências reverberam para as marcas próprias (de propriedade e responsabilidade do varejo). Se há indícios de que a 
quarta geração de marcas próprias está mais presente no mercado brasileiro (Yokoyama et al., 2012), e se a literatura indica que há preocupação socioambiental nessa geração (Burt, 2000; Jonas \& Roosen, 2005; Hyman et al., 2010), este artigo pode contribuir, sim, para a realidade dos varejistas brasileiros, ainda mais se for levado em conta o fato de que o mercado de marcas próprias é pequeno, se comparado a países do Reino Unido e escandinavos.

\subsection{Limitações da pesquisa}

Como se trata de um método qualitativo, Qu \& Dumay (2011) alertam que os entrevistados são pessoas que podem ser influenciadas pelas políticas da organização em que trabalham e, portanto, não podem ser vistas como uma fonte de verdade objetiva. Ou seja, o contexto organizacional e suas políticas (incluem-se aqui as políticas de rígido controle de informações) interferem na opinião dos entrevistados. A interpretação dos dados pode sofrer influência da subjetividade do pesquisador. Portanto, entrevistado e entrevistador podem emprestar sua subjetividade e filtros por meio dos quais enxergam determinados fatos.

Outras críticas feitas ao método qualitativo dizem respeito à generalização e confiabilidade dos resultados.

A confiabilidade pôde ser melhorada, na medida em que trechos mais importantes das respostas dos entrevistados foram explicitados nas análises dos resultados. As principais perguntas feitas foram expostas no apêndice deste trabalho, sendo lastreadas em variáveis que derivaram da literatura.

Já sobre a questão da generalização, Flick (2004) lembra que a generalização numérica não necessariamente é a correta, visto que muitos estudos qualitativos visam a desenvolver novos insights e teorias. Ainda de acordo com o autor, o estudo qualitativo foca mais na qualidade das decisões de amostragem (fundamentais para a generalização) do que no número de casos estudados. Assim, o importante é quais casos serão estudados, em vez de quantos e o que os casos representam ou para que foram selecionados.

Em função das poucas evidências por empresa estudada, não é possível fazer generalizações, mas sim aproximações. Mesmo tendo havido a contagem e frequência (vide os Quadros 1a, 2a e 3a do Apêndice A) das palavras (derivadas das falas dos entrevistados) que compuseram o campo semântico, Minayo (2012) lembra que a tentativa de realizar uma compreensão do material empírico de maneira técnica (leia-se quantitativa) pode empobrecer os resultados. É lógico que a análise do material empírico, para a autora, deve ultrapassar o nível descritivo. E se o pesquisador ficar aprisionado às falas dos entrevistados, isso pode significar sua fraqueza para realizar uma análise qualitativa. Nesse sentido, o diálogo entre o material empírico deste artigo foi feito com a teoria levantada na literatura na medida do possível. Com isso, houve certamente uma inclinação a uma análise mais descritiva do que interpretativa. No entanto, isso não pode ser visto como um demérito, já que todo o procedimento metodológico pode ser replicado e validado.

\subsection{Futuras linhas de pesquisa}

Uma vez que este trabalho concentrou seus objetivos na interface do grande varejo e fornecedores de marcas próprias, abrem-se algumas possibilidades de estudos futuros. Uma delas seria pesquisar como esses objetivos seriam respondidos em se tratando de médios e pequenos varejistas. Isso porque na Europa, por exemplo, segundo Hatanaka et al. (2005), até mesmo cadeias de varejo consideradas menores têm comercializado produtos com selos "Fairtrade Coffee".

Outros estudos poderiam verificar a suposta influência do apelo sustentável de produtos de marcas próprias na preferência ou não de compra dos consumidores, se possível quantificando com dados de venda. Uma possibilidade alternativa seria entrevistar fornecedores estrangeiros (de países desenvolvidos e em desenvolvimento) e verificar como eles se posicionam diante das exigências de padrões de sustentabilidade socioambientais das cadeias varejistas transnacionais e se essas exigências são maiores ou menores do que as legislações internas dos países onde estão sediados.

\section{Referências}

Ailawadi, K. L., \& Keller, K. L. (2004). Understanding retail branding: conceptual insights and research priorities. Journal of Retailing, 80(4), 331-342. http:// dx.doi.org/10.1016/j.jretai.2004.10.008.

Andersen, M., \& Skjoett-Larsen, T. (2009). Corporate social responsibility in global supply chains. Supply Chain Management: An International Journal, 14(2), 75-86. http://dx.doi.org/10.1108/13598540910941948.

Anselmsson, J., \& Johansson, U. (2007). Corporate social responsibility and the positioning of grocery brands: an exploratory study of retailer and manufacturer brands at point of purchase. International Journal of Retail \& Distribution Management, 35(10), 835-856. http:// dx.doi.org/10.1108/09590550710820702.

Anselmsson, J., \& Johansson, U. (2009). Third generation of retailer brands - retailer expectations and consumer response. British Food Journal, 111(7), 717-734. http:// dx.doi.org/10.1108/00070700910972396.

Associação Brasileira de Marcas Próprias e Terceirização - ABMAPRO (2011). $17^{\circ}$ Estudo Anual de Marcas Próprias 2011 Nielsen (pp. 1-37). Recuperado em 10 de julho de 2012, de http://www.abmapro.org.br/ downloads/estudoAnual2012.pdf. 
Associação Brasileira de Marcas Próprias e Terceirização - ABMAPRO (2012). Marca própria. Recuperado em 10 de julho de 2012, de http://www.abmapro.org.br/ page/marcapropria_panorama.asp.

Bardin, L. (2011). Análise de conteúdo. São Paulo: Edições 70.

Burt, S. (2000). The strategic role of retail brands in British grocery retailing. European Journal of Marketing, 34(8), 875-890. http://dx.doi.org/10.1108/03090560010331351.

Carrascoza, J. L. A. (1999). A evolução do texto publicitário - A associação de palavras como elemento de sedução na propaganda (6 ed.). São Paulo: Futura. 214 p.

Carrefour (2010). Sustentabilidade. Recuperado em 12 de agosto de 2010, de https://www.carrefour.com.br/ sustentabilidade/responsabilidade_social/

Chimhundu, R., Hamlin, R. P., \& McNeill, L. (2011). Retailer brand share statistics in four developed economies from 1992 to 2005: some observations and implications. British Food Journal, 113(3), 391-403. http://dx.doi. org/10.1108/00070701111116455.

Citelli, A. O. (1995). Linguagem e persuasão. São Paulo: Ática. 98 p.

Delai, I., \& Takahashi, S. (2013). Corporate sustainability in emerging markets: insights from the practices reported by the Brazilian retailers. Journal of Cleaner Production, 47, 211-221. http://dx.doi.org/10.1016/j. jclepro.2012.12.029.

Doz, Y. (2011). Qualitative research for international business. Journal of International Business Studies, 42(5), 582-590. http://dx.doi.org/10.1057/jibs.2011.18.

Flick, U. (2004). Uma introdução à pesquisa qualitativa (2 ed.). Porto Alegre: Bookman.

Friedman, A. L., \& Miles, S. (2002). Developing stakeholder theory. Journal of Management Studies, 39(1), 1-21. http://dx.doi.org/10.1111/1467-6486.00280.

Friedman, M. (1970). The social responsibility of business is to increase its profits. New York: New York Times.

Gooner, R. A., \& Nadler, S. S. (2012). Abstracting empirical generalizations from private label brand research. Journal of Marketing Theory and Practice, 20(1), 87-104. http:// dx.doi.org/10.2753/MTP1069-6679200106.

Grupo Pão de Açúcar - GPA (2010). Diretrizes de sustentabilidade. Recuperado em 12 de agosto de 2010, de http://www.gpabr.com/sustentabilidade/iniciativas.htm

Hatanaka, M., Bain, C., \& Busch, L. (2005). Third-party certification in the global agrifood system. Food Policy, 30(3), 354-369. http://dx.doi.org/10.1016/j. foodpol.2005.05.006.

Huang, Y., \& Huddleston, P. (2009). Retailer premium own-brands: creating customer loyalty through own-brand products advantage. International Journal of Retail \& Distribution Management, 37(11), 975-992. http:// dx.doi.org/10.1108/09590550910999389.
Hyman, M. R., Kopf, D. A., \& Lee, D. (2010). Private label brands: benefits, success factors and future research. Journal of Brand Management, 17(5), 368-389. http:// dx.doi.org/10.1057/bm.2009.33.

Instituto Ethos de Empresas e Responsabilidade Social (2007). Indicadores Ethos de Responsabilidade Social Empresarial. São Paulo: Instituto Ethos. Recuperado em 23 de junho de 2012, de http://www3.ethos.org.br/wp-content/ uploads/2013/07/IndicadoresEthos_2013_PORT.pdf.

Jonas, A., \& Roosen, J. (2005). Private labels for premium products - the example of organic food. International Journal of Retail \& Distribution Management, 33(8), 636-653. http://dx.doi.org/10.1108/09590550510608412.

Jones, P., Comfort, D., \& Hillier, D. (2011). Sustainability in the global shop window. International Journal of Retail \& Distribution Management, 39(4), 256-271. http://dx.doi.org/10.1108/09590551111117536.

Kotzab, H., Munch, H. M., de Faultrier, B., \& Teller, C. (2011). Environmental retail supply chains: when global Goliaths become environmental Davids. International Journal of Retail \& Distribution Management, 39(9), 658-681. http://dx.doi.org/10.1108/09590551111159332.

Kremer, F., \& Viot, C. (2012). How store brands build retailer brand image. International Journal of Retail \& Distribution Management, 40(7), 528-543. http:// dx.doi.org/10.1108/09590551211239846.

Lewis, L. E., Schmidt, K., \& Duvall, M. N. (2012). Retailer sustainability and the supply chain. Natural Resources and Environment, 26(4), 1-5.

Macedo, L. C. (2004). Varejista X: Projeto GTO. In J. Parente (Coord.), Responsabilidade social no varejo: conceitos, estratégias e casos no Brasil (pp. 128-132). São Paulo: Saraiva.

Minayo, M. C. (2012). Análise qualitativa: teoria, passos e fidedignidade. Ciencia \& Saude Coletiva, 17(3), 621-626. http://dx.doi.org/10.1590/S1413-81232012000300007. PMid:22450402

Morton, F. S., \& Zettelmeyer, F. (2004). The strategic positioning of store brands in retailer-manufacturer negotiations. Review of Industrial Organization, 24(2), 161-194. http:// dx.doi.org/10.1023/B:REIO.0000033350.25229.d6.

Nenycz-Thiel, M. (2011). Private labels in Australia: a case where retailer concentration does not predicate private label share. Journal of Brand Management, 18(8), 624-633. http://dx.doi.org/10.1057/bm.2010.57.

Nidumolu, R., Prahalad, C. K., \& Rangaswami, M. R. (2009). Why sustainability is now the key driver of innovation. Harvard Business Review, 1-9.

Parente, J., Macedo, L. C., Cardoso, R., \& Freiria, V. (2004). Varejo socialmente responsável. In J. Parente (Coord.), Responsabilidade social no varejo: conceitos, estratégias e casos no Brasil (pp. 3-17). São Paulo: Saraiva. 
Pérez, J. A. P., \& Gallo, M. P. (2003). Marcas de distribuidor: más de 30 años de um processo dinâmico, competitivo e imparable. Distribución y Consumo, 55-71.

Piato, É. L., Paula, V. A. F., Yokoyama, M. H., \& Pimenta, M. L. (2011). Marcas próprias no canal de distribuição. In E. L. Piato, V. A. F. Paula \& A. L. Silva (Orgs.), Gestão de marcas próprias: novas dimensões para indústria, atacado e varejo (pp. 123-167). São Paulo: Atlas.

Qu, S. Q., \& Dumay, J. (2011). The qualitative research interview. Qualitative Research in Accounting \& Management, 8(3), 238-264. http://dx.doi.org/10.1108/11766091111162070.

Reuter, C., Foerstl, K., Hartmann, E., \& Blome, C. (2010). Sustainable global supplier management: the role of dynamic capabilities in achieving competitive advantage. Journal of Supply Chain Management, 46(2), 45-63. http://dx.doi.org/10.1111/j.1745-493X.2010.03189.x.

Richardson, R. J. (1999). Pesquisa social: métodos e técnicas. São Paulo: Atlas.

Silva, A. L., Piato, É. L., Paula, V. A. F., \& Hingley, M. K. (2011). Marcas próprias. In E. L. Piato, V. A. F. Paula \& A. L. Silva (Orgs.), Gestão de marcas próprias: novas dimensões para indústria, atacado e varejo (pp. 72-98). São Paulo: Atlas.

Timlon, J. (2011). Sustainable strategic sourcing decisions: the logic of appropriateness applied to the Brazilian market. Strategic Outsourcing: An International Journal, 4(1), 89-106. http://dx.doi.org/10.1108/17538291111108444.
Walmart Brasil (2010). Pilares de sustentabilidade do Walmart. Recuperado em 12 de agosto de 2010, de http://www.walmartbrasil.com.br/sustentabilidade/home/

Walmart Brasil (2012). Relatório de sustentabilidade. Barueri: Walmart Brasil. 76 p.

Wiese, A., Kellner, J., Lietke, B., Toporowski, W., \& Zielke, S. (2012). Sustainability in retailing - a summative content analysis. International Journal of Retail \& Distribution Management, 40(4), 318-335. http://dx.doi. org/10.1108/09590551211211792.

Williamson, O. E. (2000). The new institutional economics: taking stock, looking ahead. Journal of Economic Literature, 38(3), 595-613. http://dx.doi.org/10.1257/ jel.38.3.595.

Yin, R. K. (2010). Estudo de caso: planejamento e métodos (4 ed.). Porto Alegre: Bookman.

Yokoyama, M. H., Silva, A. L., \& Piato, É. L. (2012). O desenvolvimento de marcas próprias: estudo comparativo entre o varejo e fornecedores da indústria alimentícia. Gestão \& Produção, 19(3), 543-556. http://dx.doi. org/10.1590/S0104-530X2012000300008.

Zutshi, A., Creed, A., \& Sohal, A. (2009). Child labour and supply chain: profitability or (mis)management. European Business Review, 21(1), 42-63. http://dx.doi. org/10.1108/09555340910925175. 
Apêndice A. Análise de conteúdo (Contagem, frequência e codificação).

Os Quadros 1a, 2a e 3a dizem respeito à contagem e frequência das palavras pertencentes aos campos semânticos, cujos paradigmas dão nome às categorias temáticas. Foram contabilizadas as frequências com que as palavras das respostas dos entrevistados pertencentes ao campo semântico (categoria temática) apareceram. Serviram para que a codificação e nomeação das categorias fossem mais precisas. Ou seja, contribuíram para uma fase anterior à própria análise dos dados.

Quadro 1a. Contagem e frequências nas falas dos entrevistados na categoria temática "Contratos".

\begin{tabular}{|c|c|c|c|c|}
\hline & $\begin{array}{l}\text { CONTRATOS (categoria } \\
\text { temática por critério semântico e } \\
\text { paradigma do campo semântico) }\end{array}$ & $\begin{array}{l}\text { Total de palavras } \\
\text { transcritas } \\
\text { correspondentes } \\
\text { à variável e às } \\
\text { falas/documentos } \\
\text { selecionados de } \\
\text { cada entrevistado }\end{array}$ & $\begin{array}{l}\text { Número de } \\
\text { palavras } \\
\text { relevantes do } \\
\text { campo semântico } \\
\text { (escolha lexical) }\end{array}$ & $\begin{array}{c}\text { Porcentagem } \\
\text { de palavras do } \\
\text { campo semântico } \\
\text { sobre o total } \\
\text { da fala de cada } \\
\text { entrevistado }\end{array}$ \\
\hline Varejista Y & $\begin{array}{l}\text { licenças ambientais, conformidade, } \\
\text { legislação }\end{array}$ & 43 & 4 & $9,30 \%$ \\
\hline Varejista X & certificação, controle & 71 & 2 & $2,82 \%$ \\
\hline Varejista $\mathbf{Z}$ & $\begin{array}{l}\text { "compras éticas", "responsabilidade } \\
\text { social", "questões ambientais", } \\
\text { "avaliação de fornecedores", } \\
\text { "contratos assinados", parceiros, } \\
\text { cláusulas, "respeito às leis", } \\
\text { "respeito às leis ambientais", } \\
\text { "condições de trabalho", "condições } \\
\text { de emprego". }\end{array}$ & 179 & 26 & $14,53 \%$ \\
\hline $\begin{array}{c}\text { Fornecedor } \\
\text { B }\end{array}$ & $\begin{array}{l}\text { "são exigidas", "é condição", } \\
\text { certificadas, "não pode ter mão de } \\
\text { obra escrava", "não pode ter menor } \\
\text { trabalhando", "pague todos os } \\
\text { impostos", auditada }\end{array}$ & 117 & 20 & $17,09 \%$ \\
\hline $\begin{array}{c}\text { Fornecedor } \\
\text { A }\end{array}$ & $\begin{array}{l}\text { auditoria, "esse ponto não era tão } \\
\text { visado", "cada vez mais" }\end{array}$ & 29 & 10 & $34,48 \%$ \\
\hline $\begin{array}{c}\text { Fornecedor } \\
\text { C }\end{array}$ & $\begin{array}{l}\text { "amarrado via contrato", "posso até } \\
\text { perder o fornecimento", "desvio de } \\
\text { conduta", "sofrer as sanções legais", } \\
\text { cobrado, "parte social", auditorias, } \\
\text { "não ter mão de obra escrava, } \\
\text { infantill" }\end{array}$ & 64 & 24 & $\mathbf{3 7 , 5 0 \%}$ \\
\hline
\end{tabular}

Fonte: Elaborado pelos autores (2014). 
Quadro 2a. Contagem e frequências nas falas dos entrevistados na categoria temática "Verificação".

\begin{tabular}{|c|c|c|c|c|}
\hline & $\begin{array}{c}\text { VERIFICAÇÃO (categoria } \\
\text { temática por critério semântico } \\
\text { e paradigma do campo } \\
\text { semântico) }\end{array}$ & $\begin{array}{c}\text { Total de palavras } \\
\text { transcritas } \\
\text { correspondentes } \\
\text { à variável e às } \\
\text { falas/documentos } \\
\text { selecionados de cada } \\
\text { entrevistado } \\
\end{array}$ & $\begin{array}{l}\text { Número de } \\
\text { palavras } \\
\text { relevantes } \\
\text { do campo } \\
\text { semântico } \\
\text { (escolha } \\
\text { lexical) } \\
\end{array}$ & $\begin{array}{c}\text { Porcentagem } \\
\text { de palavras do } \\
\text { campo semântico } \\
\text { sobre o total } \\
\text { da fala de cada } \\
\text { entrevistado }\end{array}$ \\
\hline Varejista Y & $\begin{array}{l}\text { "auditoria de homologação", } \\
\text { "auditado", "índice de qualidade", } \\
\text { score, regularidade }\end{array}$ & 44 & 9 & $20,45 \%$ \\
\hline Varejista $X$ & $\begin{array}{l}\text { "empresas terceirizadas coletam", } \\
\text { "de acordo com a legislação", } \\
\text { contraprova, "auditoria uma vez } \\
\text { por ano", "análise do produto } \\
\text { no mínimo uma vez por ano", } \\
\text { "visitas não anunciadas", "firmas } \\
\text { de auditoria terceirizadas", } \\
\text { "fiscalização", "auxílio de ONG’s } \\
\text { parceiras" }\end{array}$ & 83 & 35 & $42,17 \%$ \\
\hline Varejista Z & $\begin{array}{l}\text { auditorias, garantir, "coisas estão } \\
\text { sendo mantidas", inspeções, } \\
\text { auditorias, "condições são } \\
\text { realmente efetivas" }\end{array}$ & 37 & 12 & $32,43 \%$ \\
\hline Fornecedor B & $\begin{array}{l}\text { "certificadoras mundiais", } \\
\text { auditoria, "comprovar tudo aquilo } \\
\text { que eles estão nos exigindo" }\end{array}$ & 26 & 11 & $42,31 \%$ \\
\hline Fornecedor A & $\begin{array}{l}\text { "empresa auditora", BVS, } \\
\text { SGS, "auditorias do processo } \\
\text { de fabricação", notas, valores, } \\
\text { auditoria (4 vezes), "de } 0 \text { a } 100 \\
\text { pontos, } 30 \text {, ou 40, ou 90, ou } 100 ", \\
\text { "nota nós tiramos", "empresas } \\
\text { especializadas em orgânicos", } \\
\text { Ecocert, audita, "se a empresa } \\
\text { tem ou não condições de fornecer } \\
\text { produtos orgânicos" }\end{array}$ & 125 & 47 & $37,60 \%$ \\
\hline Fornecedor C & $\begin{array}{l}\text { "boas práticas de fabricação", } \\
\text { Anvisa ( } 2 \text { vezes), inspeção, } \\
\text { documentações, certificações }\end{array}$ & 105 & 9 & $8,57 \%$ \\
\hline
\end{tabular}

Fonte: Elaborado pelos autores (2014). 
Quadro 3a. Contagem e frequências nas falas dos entrevistados na categoria temática "Importação".

\begin{tabular}{|c|c|c|c|c|}
\hline & $\begin{array}{c}\text { IMPORTAÇÃO } \\
\text { (categoria temática por critério } \\
\text { semântico e paradigma do } \\
\text { campo semântico) }\end{array}$ & $\begin{array}{c}\text { Total de palavras } \\
\text { transcritas } \\
\text { correspondentes } \\
\text { à variável e às } \\
\text { falas/documentos } \\
\text { selecionados de cada } \\
\text { entrevistado } \\
\end{array}$ & $\begin{array}{l}\text { Número de } \\
\text { palavras } \\
\text { relevantes } \\
\text { do campo } \\
\text { semântico } \\
\text { (escolha } \\
\text { lexical) }\end{array}$ & $\begin{array}{c}\text { Porcentagem } \\
\text { de palavras do } \\
\text { campo semântico } \\
\text { sobre o total } \\
\text { da fala de cada } \\
\text { entrevistado }\end{array}$ \\
\hline Varejista Y & $\begin{array}{l}\text { "inspeção na origem", "produtos } \\
\text { importados", "adequação", } \\
\text { "regulamentação nacional", } \\
\text { "Global Sourcing", seleciona, } \\
\text { audita, "critérios de qualidade } \\
\text { de normas internacionais", BRC } \\
\text { (British Retail Consortium) }\end{array}$ & 52 & 22 & $42,31 \%$ \\
\hline Varejista $X$ & $\begin{array}{l}\text { "fornecedor na China", "empresas } \\
\text { mundiais", Chile, Argentina, } \\
\text { "fornecedores na Argentina e no } \\
\text { Chile", "obedecer à legislação do } \\
\text { país de origem", "produto entra } \\
\text { no Brasil", "produto entra via } \\
\text { importação", "trâmites legais" }\end{array}$ & 80 & 30 & $37,50 \%$ \\
\hline Varejista $\mathbf{Z}$ & $\begin{array}{l}\text { "Ethical Sourcing", "fornecedores } \\
\text { em âmbito mundial", "contratos } \\
\text { para importação direta", "Global } \\
\text { Merchandise Centers (GMC)", } \\
\text { "Direct Sourcing Group (DSG)", } \\
\text { "estruturas da empresa em nível } \\
\text { global", "desmatamento lá na } \\
\text { Indonésia, ou lá na Malásia" }\end{array}$ & 95 & 32 & $33,68 \%$ \\
\hline
\end{tabular}

Fonte: Elaborado pelos autores (2014). 
Apêndice B. Roteiro de Entrevistas.

Algumas perguntas aos varejistas

1) Quando esta empresa firma contratos de fornecimento de produtos marcas próprias, são levados em conta indicadores e certificações socioambientais? Quais?

2) Como vocês se asseguram de que as cláusulas de responsabilidade social e ambiental estão sendo efetivamente cumpridas pelos fornecedores de marca própria? Como e com que frequência são feitas as visitas de inspeção aos fabricantes de marca própria?

3) E quando os fornecedores dos produtos marcas próprias são de outros países, como são feitas essas visitas de inspeção/auditoria socioambiental?

Algumas perguntas aos fornecedores de produtos marcas próprias

1) Como são feitos os controles de qualidade e dos aspectos socioambientais? São feitos na mesma auditoria ou em auditorias separadas?

2) Os varejistas o ajudam nesse processo de auditoria ou simplesmente exigem que você já tenha todos os critérios que eles cobram?

3) Vocês têm alguma certificação que comprove a preocupação ambiental e social da empresa de vocês perante o comprador varejista?

4) Essas exigências são feitas via contrato?

5) Você acha que foi bom para o seu negócio fornecer marcas próprias? Por quê? 